\title{
In vitro antibacterial and cytogenotoxicological properties of the aqueous extract of Cymbopogoncitratus Stapf (DC) leaf
}

\author{
Joseph Omorogiuwa Erhabor ${ }^{1,2}$, Rosemary Chinelo Erhabor ${ }^{1}$, MacDonald ldu $^{1}$
}

1. Department of Plant Biology and Biotechnology, Faculty of Life Sciences, University of Benin, Benin City, Nigeria. 2. Phytomedicine Programme, Department of Paraclinical Sciences, Faculty of Veterinary Sciences, University of Pretoria, South Africa.

\begin{abstract}
Background: Microbial infection of the genital tract or semen is one of the leading causes of male infertility. Consequently, there is a need to seek alternative products from natural sources.

Objectives: The antibacterial, phytochemical and cytogenotoxicological assessments of the aqueous extract of Cymbopogon citratus leaf were evaluated.

Methods: The antibacterial potential of the extract was done via agar-well diffusion and microdilution techniques. The phytochemical analysis was done via standard protocols. The cytogenotoxicity of the extract were analyzed using the Allium cepa assay. Results: All test organisms were found to be sensitive to the extract except Psendomonas. aeruginosa where no measurable zone of inhibition could be ascertained at all concentrations assessed.The highest mean inhibition diameter of $21.33 \pm 1.20 \mathrm{~mm}$ against $S$. sapophyticus was recorded and a concentration-dependent susceptibility noticed. The phytochemical results revealed the presence of saponins, flavonoid, glycoside, steroids, terpenoid and alkaloids. The Alliumcepa root showed reduced mitotic indices following aconcentration-dependent increase in the extract.It can be said that the aqueous extract of $C$. citratus had inhibitory activities against the tested pathogenic organisms with relative anti-tumour potential.

Conclusion: This study indicated, C. citratus could be a potential source for antibacterial compounds for the possible treatment of male reproductive related infections.

Keywords: Antibacterial, cytogenotoxicity, phytochemistry, medicinal plant, Cymbopogon citratus.

DOI: https://dx.doi.org/10.4314/ahs.v19i2.29

Cite as: Erbabor JO, Erbabor RC, ldu M. In vitro antibacterial and cytogenotoxicological properties of the aqueous extract of Cymbopogon citratusStapf (DC) leaf. Afri Health Sci.2019;19(2): 2056-2067. https:/ / dx.doi.org/10.4314/ abs.v19i2.29
\end{abstract}

\section{Introduction}

Plants generally serve innumerable purposes and can be used in the form of food, textile and shelter, as medicine and in religious practices ${ }^{1}$. The ethnomedicinal use of plants is an ancient practice that is still very relevant up till date. Medicinal plants are to a great extent considered affordable, reliable and constitute a cultural heritage to rural and most urban people ${ }^{2}$. Medicinal plants are of abundant importance to the health of individuals and so-

\section{Corresponding author: \\ Joseph Omorogiuwa Erhabor, \\ Department of Plant Biology and Biotechnology, \\ Faculty of Life Sciences, \\ University of Benin, Benin City, Nigeria, \\ Tel: +2348077979390 \\ Email: joseph.erhabor@uniben.edu}

cieties. The use of traditional medicines and medicinal plant in most countries as therapeutic agents had help in the maintenance of good health and production of local herbal drugs. Also, the frequent use of these plants had indeed fuelled the awareness of medicinal plants been a re-emerging health relief ${ }^{3}$. In Nigeria, like in other countries, traditional medicines are used in treating a lot of health conditions such as infertility, mental disorder, and fractures ${ }^{4}$.

Moreover, one of the leading causes of male infertility today is microbial infection of the genital tract or semen ${ }^{5,6}$. Pellati et $\mathrm{al}^{7}$ observed that infections of the male genitourinary tract account for up to $15 \%$ of cases of male infertility. Qualitative and quantitative sperm alterations have been shown in recent studies to be due to acute and chronic infections, resulting in the inflammation of the male reproductive system, thereby compromising the

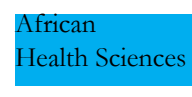

(C) 2019 Erhabor et al. Licensee African Health Sciences. This is an Open Access article distributed under the terms of the Creative commons Attribution License (https://creativecommons.org/licenses/BY/4.0), which permits unrestricted use, distribution, and reproduction in any medium, provided the original work is properly cited. 
sperm function and the entire spermatogenetic process ${ }^{8}$. Further deterioration of spermatogenesis, obstruction of seminal tract and effect of spermatozoa function may be caused by cellular reactions against microbial agents or by direct influence of pathological bacterial strains on gametogenic cells". Semen contamination by bacterial, generally originate from the urinary tract of patients or can be transmitted by the partner via sexual intercourse ${ }^{10}$. Though the effect of bacteriospermia on sperm quality is still said to be controversial, many studies have however examined the impact of genital tract infections on male infertility ${ }^{11}$. Considering the problems of infertility in our society and the pain and anxiety caused by the inability of couple to procreate, microbiological investigation of the semen of male partners to detect microbial agents causing infertility can be useful intervention at resolving the problems of infertility ${ }^{6,12}$. Following ethnomedical reports, Cymbopogon citratus (Lemon grass) have been implicated in treating some microbial infections such as urinary tract infection, skin eruptions and in managing general infertility ${ }^{13}$.

The proximate and nutrient analysis of eatable fruits, vegetables and medicinal plants play a critical role in assessing their nutritional significance. It has become indispensable with various medicinal plant species used as food along with their medicinal benefits, that evaluating their nutritional significance will further provide the required understanding of the value of these plant species ${ }^{14}$. Lemon grass no doubt will have noteworthy bioactive compounds having been implicated in many health issues as have been noted previously and in other studies ${ }^{13,15,16}$. Lemon grass is widely used for medicinal purposes and orally consumed. Therefore, it becomes necessary to establish its toxic status. Toxicity, a biological safety tool is said to be the damage made on an organism by any substance ${ }^{17}$. These effects can be on organisms such as animal, bacterium, or plant, as well as the effect on a sub-structure of the organism, such as cell (cytotoxicity) or the liver (hepatotoxiity). The toxicity of a sample can be accessed by the evaluation of macroscopic and microscopic parameters where the rate of chromosome breakage and damage will be used to predict mutagenesis. The Allium cepa assay is one such assay that have been explored. The Allium cepa is a plant widely used for cytotoxicity and genetoxicological studies. This assay is a sensitive test that have been use to determine cyto-genotoxic effects of various chemical substances ${ }^{18,19}$. The importance of the test cannot be over-emphasized as it has provided information on toxicity prevention in the environment and as a useful bio-indicator for genetoxicity ${ }^{20}$. The test which have been adjudged to be more sensitive for detecting toxicity and genotoxicity than other tests have provided the pathway to identify the presence of pesticides in foods as well as in the environments ${ }^{21,22}$. This has however raised the bio-monitoring level as the onion roots are said to be sensitive to a wide range of toxic materials ${ }^{23}$.

Cymbopogon citratus Stapf (DC) commonly called lemon grass is a tall, Asian grass; long known for its attractive scent and medicinal properties. It is a dense, clump forming grass. The strap-like leaves are $0-5.1 \mathrm{~cm}$ wide, $3 \mathrm{ft}$ long and have graceful dropping tips, releasing a citrus aroma when crushed. The green leaf is simple, linear and has a blade length of $18-36$ inch. The inflorescences are about $30-60 \mathrm{~cm}$ long and partial inflorescences are paired racemes of spikelet subtended by spathes.Earlier report on the biological activities of the essential oils and various leaf extract/fractions of C. citratus abound in literature. These include ascaricidal activity ${ }^{24}$, analgesic activity $^{25}$, anti-amoebic activity ${ }^{26}$, antibacterial activity ${ }^{27,28}$, anticonvulsant activity ${ }^{29}$, antimalarial activity $^{30}$, anti-mycobacterial activity ${ }^{31}$ and dermatitis producing effects ${ }^{32}$. Traditionally a decoction of the entire plant is applied externally on wounds and bone fractures. A hot water extract of the dried leaves is taken orally as a hypotensive and for catarrh and rheumatism ${ }^{33}$. Again, a decoction of the dried leaves and stem taken orally by the Egyptians is a renal antispasmodic diuretic while the entire plant is said to repel snakes ${ }^{34}$. The extract of the dried root in hot water is taken orally for diabetes while that of the dried leaves is used to treat ulcer, bruises, skin eruptions and urinary tract infections ${ }^{35}$. In Nigeria, a decoction of the leaves as reported by Erhabor et. $\mathrm{al}^{13}$ can be used to manage weak erection and general infertility ailments.

This study therefore was undertaken to determine the antimicrobial effects against microorganisms isolated from semen, qualitative phytochemical properties and cytogenotoxicological effects of the aqueous extract of $C$. citratus leaf. 


\section{Materials and methods}

\section{Collection and identification of plant material}

Healthy matured leaves of C. citratus were collected in June 2014 from Benin City, Nigeria. The plant with a voucher specimen (UBHp0185) was authenticated by Prof MacDonald Idu and deposited at the herbarium of the Department of Plant Biology and Biotechnology, Faculty of Life sciences, University of Benin, Nigeria.

\section{Preparation and extraction of plant material}

The collected leaves were initially rinsed under running tap water and air dried on laboratory tables at room temperature. The leaves were dried in the oven at a set temperature of $40^{\circ} \mathrm{C}$ for 15 minutes. The plant was reduced to fine powder with the aid of a mechanical grinder and stored in tightly covered glass jars until required. The powdered leaf sample (1250 g) was extracted using a Soxhlet extractor with $2500 \mathrm{ml}$ of distilled water. The extract was concentrated to dryness using the water bath at a temperature set at $45^{\circ} \mathrm{C}$. Water was used as the extracting solvent following its wide use in traditional medicine in preparing most herbal concoctions.

\section{Evaluation of antibacterial activity Collection of semen samples}

The semen samples were collected following the method described by Ekhaise and Richard ${ }^{6}$. The seminal fluid specimens were collected from five male patients with secondary infertility, attending fertility clinic at two private hospitals in Benin City, Nigeria. The samples were collected using the masturbation method. The collected samples were immediately taken to the laboratory. The study was exempted from any formal ethical approval by the Institutional ethics committee of the University of Benin. The requisite for consent was waived and considered unnecessary by the Institutional ethics committee.

\section{Isolation, identification and standardization of bac- teria isolates}

The respective sperm specimens were streaked on blood agar and nutrient agar and incubated for $24 \mathrm{hrs}$ at $37^{\circ} \mathrm{C}$. The bacterial species after incubation were identified via gram staining and appropriate biochemical tests following standard procedures as described by Cheesbrough ${ }^{36}$ .A loop full of stock culture of the organism was inocu- lated onto $5 \mathrm{ml}$ of sterilized Muller-Hinton agar and incubated for $24 \mathrm{hrs} .0 .2 \mathrm{ml}$ of overnight culture of the organisms were inoculated onto $20 \mathrm{ml}$ of sterile nutrient broth and incubated for 3-5 hrs. The turbid level of the culture was compared with 0.5 Mac-Farland to standardize the culture to $10^{6} \mathrm{cfu} \backslash \mathrm{ml}$.

\section{Susceptibility testing}

Following the procedure pronounced by Emeruwa ${ }^{37}$, $0.5 \mathrm{ml}$ of the standardized culture was spread onto a sterile plate to achieve confluent growth. Fifteen milliliters $(15 \mathrm{ml})$ of Muller-Hinton agar at $45^{\circ} \mathrm{C}$ was added to each plate and the plates were rocked for even spread and proper mixing of bacteria and agar. The plates were allowed to solidify and holes of $6 \mathrm{~mm}$ diameter was bored on the surfaces of the agar medium using a sterile cork borer and the holes seeded with molten agar. The reconstituted extract $(0.2 \mathrm{ml})$ was introduced into the holes while an aqueous solution of the standard antibiotics (chloramphenicol) concentrations served as positive control. The plates were allowed to stand for 30 minutes for pre-diffusion of the extract to occur and then incubated at $37^{\circ} \mathrm{C}$ for $24 \mathrm{hrs}$. The zones of inhibition were measured to the nearest $\mathrm{mm}$ using a meter rule. The mean of duplicate results were taken.

\section{Determination of minimum inhibitory concentra- tions (MICs)}

Initially, bacterial strains cultured overnight at $37^{\circ} \mathrm{C}$ on nutrient broth were adjusted to a final density of $10^{6} \mathrm{cfu} \backslash$ $\mathrm{ml}$. The respective strains was used to inoculate the 96well microtitre plates with serial dilutions of the extract and positive control ranging from $12.5-0.098 \mathrm{mg} / \mathrm{ml}$ under aseptic conditions. The plates were incubated under aerobic condition at $37^{\circ} \mathrm{C}$ and examined after $24 \mathrm{hrs}$. As an indicator of bacterial growth, $40 \mu \mathrm{L}$ of $0.2 \mathrm{mg} / \mathrm{ml}$ piodonitrotetrazolium violet (INT) was added to the wells and incubated for 30 minutes at $37^{\circ} \mathrm{C}$. As a measure of the biological activity of the organisms, the colourless tetrazolium salt will be reduced to a red-pink formazan. Each treatment was performed in triplicate and a complete suppression of growth at a specific concentration of the extract indicated by a clear solution was used in determining the minimum inhibitory concentration of the extract $^{38}$. The positive control was chloramphenicol while the diluent-10\% DMSO served as the negative control. 


\section{Determination of minimum bactericidal concentra- tions (MBCs)}

The values were determined by taking out a loop full of the respective bacterial suspension from the MIC micro-titre plates that did not show any growth and sub -cultured into nutrient agar plates. The plates were incubated and the concentrations at which no visible growth was observed were recorded as MBC.

\section{Phytochemical and proximate analysis}

The qualitative chemical test was carried out on the aqueous extract of $C$. citratus leaves using previously reported procedures $^{39,40}$. The various food parameters in the sample were also estimated ${ }^{41}$.

\section{Cytogenotoxicological analysis Source and preparation of materials}

The bulbs of the common purple variety of Allium cepa $L$. was used in the study. The comparatively similar onions in size and weight were purchased in Benin City, Nigeria. The onions were stored in dry and well aerated conditions for several weeks before use. The other materials include dilute $\mathrm{HCl}(1 \mathrm{~N} \mathrm{HCl})$, ethanol:acetic acid (3:1), distilled water, tap water, slides, cover slips, meter rule and acetone orcein dye.

In preparing the onion bulbs, the dried, mouldy and those with shooting green leaves were discarded. The outer scales of the selected bulbs were carefully removed with hand while the dried root tips at the base of the bulbs were shaved off carefully with a new sharp razor blade to expose the fresh meristematic tissues. The method described by Olorunfemi et $\mathrm{al}^{42}$ was adopted for this bioassay.

\section{Macroscopic and microscopic evaluations}

The shaved bulbs which were initially placed in distilled water were removed and placed on a soft layer of tissue paper to take out excess water. The bulbs were rinsed with distilled water to protect the primordial cell from drying ${ }^{23}$. Immediately, the base of five onion bulbs each were individually placed into the appropriately labelled 80 $\mathrm{ml}$ plastic cups containing freshly prepared aqueous extract of the lemon grass at different concentrations $(0.25$ $\mathrm{mg} / \mathrm{ml}, 0.50 \mathrm{mg} / \mathrm{ml}, 0.75 \mathrm{mg} / \mathrm{ml}$ and $1.00 \mathrm{mg} / \mathrm{ml}$ ) as well as the control (distilled water). The cups were all kept in the dark with the test samples and control daily changed over an exposure period of 4 days. The roots of each of the onion bulb at each of the concentrations were excised using a forceps and their length measured $(\mathrm{cm})$ respectively. The percentage root growth inhibition (overall mean root length of test solution/ overall mean root length of control X100) as well as the morphology of the roots were assessed.

Following the exposure of another set of five onion bulbs to the test samples (corresponding to each concentration) and control for 48 hours as described above, the microscopic evaluation was carried out. There after the exposed bulbs were carefully removed and the root tips excised and placed in lithium bottles containing the fixative (ethanol and acetic acid; 3:1). This was to prevent the root from becoming dried as well as not to compromise the rate of dividing cells undergoing mitosis as at the time of collecting the root. The root tips were removed after 24 hours from the lithium tubes and placed in carefully labelled petri dishes containing dilute $\mathrm{HCl}(1 \mathrm{~N} \mathrm{HCl})$. The petri dishes were carefully placed in an oven at $65^{\circ} \mathrm{C}$ for 3 minutes. This procedure was carried out to soften the tissues of the root tip for maceration. The roots were thoroughly rinsed thrice with distilled water and following standard procedures ${ }^{43}$ the slides were prepared. The slides were viewed under the light microscope. Cells were scored for frequency and type of chromosome aberrations in the dividing cells for each concentration. Mitotic index was computed by determining the mitotic cell frequency at the tip as number of dividing cells/total number of cells X 100 while the mitotic inhibition was determined using the following formula: mitotic index in control - mitotic index in treatment/ mitotic index in control X 100. The frequency of Chromosomal aberration was ascertained by: Number of Aberrant cells/ Total number of cells counted X 100. Photomicrographs of different stages were taken using an Olympus model microscope with a 5 mega pixel eye pixel digital camera.

\section{Statistical analysis}

Some of the data were expressed as mean \pm standard error of mean while others as mean \pm Standard Deviation. All data were analyzed using Statistical Package for the Social Sciences (SPSS) 16.0 computer software package. 


\section{Results}

\section{Antimicrobial activity}

The inhibitory activities of the aqueous extract of the leaf of Cymbopogon citratus against the test organisms are depicted in Table 1. The highest zone of inhibition of $21 \mathrm{~mm}$ was recorded against Staphylococcus saprophyticus at a concentration of $50 \mathrm{mg} / \mathrm{ml}$, while the lowest of $2 \mathrm{~mm}$ was recorded against Proteus mirabilis at the concentration of $25 \mathrm{mg} / \mathrm{ml}$. The result from Table 1 revealed that there was no observable measurable zone of inhibition recorded against Proteus mirabilis at all the listed concentrations and at $50 \mathrm{mg} / \mathrm{ml}$ against Proteus mirabilis and Escherichia coli.

\begin{tabular}{|c|c|c|c|}
\hline Test organisms & Concentrations of & Extract $(\mathrm{mg} / \mathrm{ml})$ & \\
\hline & 50 & 25 & 12.5 \\
\hline P. aeruginosa & NMZI & NMZI & NMZI \\
\hline P. mirabilis & $3.33 \pm 0.88$ & $2.00 \pm 0.02$ & NMZI \\
\hline E. coli & $4.00 \pm 1.15$ & $2.00 \pm 0.05$ & NMZI \\
\hline S. saprophyticus & $21.33 \pm 1.20$ & $17.67 \pm 1.20$ & $12.67 \pm 0.88$ \\
\hline K. pneumoniae & $13.00 \pm 1.15$ & $7.00 \pm 0.28$ & $3.00 \pm 0.58$ \\
\hline
\end{tabular}

Values are mean \pm SEM (zone of inhibition in $\mathrm{mm}$ ); $\mathrm{n}=\mathbf{2}$;NMZI: No measurable zone of inhibition

The minimum inhibitory concentrations (MIC) and the Minimum bactericidal concentrations (MBC) of the aqueous extract of $C$. citratus are displayed in Table 2 . It was observed that the extract had MIC of $1.56 \mathrm{mg} / \mathrm{ml}$ against Escherichia coli, Klebsiella pneumoniae and Staphylococcus saprophyticus, while at $3.13 \mathrm{mg} / \mathrm{ml}$ against Proteus mi- rabilis. There was however no inhibitory effect recorded against Pseudomonas aeruginosa. The extract had the same MBC values of $3.13 \mathrm{mg} / \mathrm{ml}$ against all test organisms except Pseudomonas aeruginosa with no observable activity. The positive control had an MIC range of 0.098 to 1.563 $\mathrm{mg} / \mathrm{ml}$ and an MBC range of 0.195 to $3.125 \mathrm{mg} / \mathrm{ml}$ (Table 2). 
Table 2: Minimum inhibitory concentration (MIC) and minimum bactericidal concentration (MBC) of aqueous extract of $C$. citrates

\begin{tabular}{lcclc}
\hline $\begin{array}{l}\text { Test } \\
\text { organisms }\end{array}$ & $\begin{array}{c}\text { Aqueous extract } \\
\text { MIC(mg/ml) }\end{array}$ & $\mathbf{M B C}(\mathbf{m g} / \mathbf{m l})$ & $\begin{array}{c}\text { Control } \\
\mathbf{M I C}(\mathbf{m g} / \mathbf{m l})\end{array}$ & $\mathbf{M B C}(\mathbf{m g} / \mathbf{m l})$ \\
\hline $\begin{array}{l}\text { Escherichia } \\
\text { coli }\end{array}$ & 1.56 & 3.13 & 0.781 & 1.563 \\
$\begin{array}{l}\text { Klebsiella } \\
\text { pneumoniae }\end{array}$ & 1.56 & 3.13 & 0.195 & 0.391 \\
$\begin{array}{l}\text { Proteus } \\
\text { mirabilis }\end{array}$ & 3.13 & 3.13 & 0.195 & 0.391 \\
$\begin{array}{l}\text { Staphylococcus } \\
\text { saprophyticus }\end{array}$ & 1.56 & 3.13 & 0.098 & 0.195 \\
$\begin{array}{l}\text { Pseudomonas } \\
\text { aeruginosa }\end{array}$ & $\mathrm{NA}$ & $\mathrm{NA}$ & 1.563 & \\
\hline
\end{tabular}

NA $=$ No activity $;$ Control $=$ Chloramphenicol

The reference drug (chloramphenicol) was seen to have inhibitory effect against all the test organisms particularly at the highest concentration of $50 \mathrm{mg} / \mathrm{ml}$ (Table 3).

Table 3: Antibiogram profile of test organisms with zones of inhibition (mm)

\begin{tabular}{llll}
\hline Organisms & \multicolumn{3}{l}{ Concentrations of Chloramphenicol $(\mathrm{mg} / \mathrm{ml})$} \\
\cline { 2 - 4 } & 12.5 & 25 & 50 \\
\hline E. coli & - & - & $10.0 \pm 0.04$ \\
K. pneumonia & $4 \pm 0.03$ & $10 \pm 0.02$ & $18.0 \pm 0.02$ \\
P. mirabilis & - & $10 \pm 0.02$ & $16.0 \pm 0.05$ \\
P. aeruginosa & - & - & $12.0 \pm 0.03$ \\
S. saprophyticus & $10 \pm 0.03$ & $15 \pm 0.02$ & $24.0 \pm 0.03$ \\
\hline
\end{tabular}

Phytochemical studies

The qualitative phytochemical analysis reveals that saponins, flavonoid, glycoside, carbohydrate, steroids, terpenoid, and alkaloids were present both in the extract and the raw powdered sample. The absence of tannins, phenol and antraquinones were observed in both samples (Table 4). The percentage composition on dry weight basis of the aqueous extract and crude powdered sample of C. citratus leaf are presented in Table 5 . 
Table 4: Qualitative phytochemical screening of the aqueous extract of Cymbopogon citratus leaf

\begin{tabular}{lcc}
\hline $\begin{array}{l}\text { Chemical } \\
\text { components }\end{array}$ & $\begin{array}{r}\text { Aqueous } \\
\text { extract }\end{array}$ & $\begin{array}{l}\text { Crude powdered } \\
\text { sample }\end{array}$ \\
\hline Saponin & + & + \\
Flavonoids & + & + \\
Carbohydrate & + & + \\
Phenol & - & - \\
Tannins & - & - \\
Steroid & + & + \\
Anthraquinones & - & - \\
Terpenoids & + & + \\
Alkaloids & + & + \\
\hline
\end{tabular}

Key: + = presence of chemical component; - = absence of chemical component

Table 5: Proximate composition (\%) of the leaf of $C$.citratus

\begin{tabular}{lll}
\hline \multicolumn{2}{l}{ ComponentsAqueous extract } & Crude powdered sample \\
\hline Moisture & $37.51 \pm 0.006$ & $10.40 \pm 0.003$ \\
Ash & $2.11 \pm 0.003$ & $4.32 \pm 0.003$ \\
Fat & $10.20 \pm 0.003$ & $15.30 \pm 0.003$ \\
Fiber & $6.31 \pm 0.002$ & $7.27 \pm 0.003$ \\
Crude Protein & $14.27 \pm 0.003$ & $15.76 \pm 0.004$ \\
N.F.E & $29.61 \pm 0.005$ & $47.01 \pm 0.012$ \\
\hline
\end{tabular}

Values are mean \pm SEM of 3 determinations on dry weight basis; N.F.E $=$ nitrogen free energy

\section{Cytogenotoxicological analysis}

Macroscopic examination of Allium cepa roots showed that, unlike the control, there was a significant concentration dependent inhibition of root growth by the aqueous extract of C. citratus at different concentrations (Table 6)
Chromosomal aberrations induced in Allium cepa exposed in different concentration of the aqueous extract of C. citratus showed multiple bridge/ polar, sticky chromosome, disoriented chromosome with polar deviation, vagrant chromosomes, and spindle disturbance cell (Table 7) 
Table 6: Effect of aqueous leaf extract of different concentrations of

C. citrates on root length of Allium cepa

\begin{tabular}{llll}
\hline $\begin{array}{l}\text { Concentrations } \\
(\mathrm{mg} / \mathrm{ml})\end{array}$ & $\begin{array}{l}\text { Mean root length } \pm \text { S.E. } \\
(\mathrm{cm})\end{array}$ & $\begin{array}{l}\text { Overall } \\
\text { of Roots }\end{array}$ & $\begin{array}{l}\text { Number } \\
\text { \% Root growth of } \\
\text { Control }\end{array}$ \\
\hline Control & $4.54 \pm 0.75$ & 100 & 100 \\
0.25 & $2.74 \pm 1.13$ & 86 & 60.35 \\
0.50 & $2.24 \pm 0.25$ & 85 & 49.34 \\
0.75 & $1.91 \pm 0.34$ & 72 & 42.07 \\
1.00 & $1.84 \pm 1.36$ & 47 & 40.53 \\
\hline & $\mathrm{n}=5$ & &
\end{tabular}

Table 7: Cytogenotoxicological analysis of Allium cepa root cells exposed to C.citratus leaf aqueous extract.

\begin{tabular}{|c|c|c|c|c|c|c|c|c|c|c|c|c|c|}
\hline 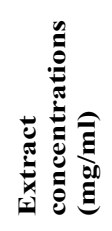 & 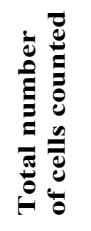 & 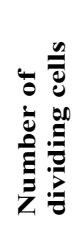 & 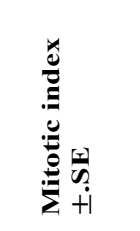 & لَّ & 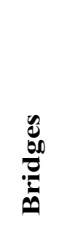 & 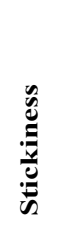 & 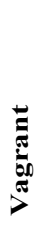 & 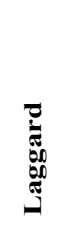 & 范 & 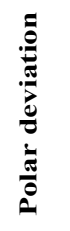 & 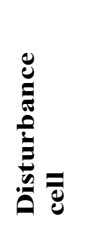 & 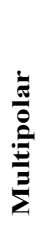 & 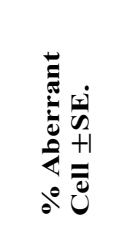 \\
\hline Control & 2023 & 219 & $10.83 \pm 0.32$ & 0 & 1 & 1 & 2 & 1 & - & - & - & - & $0.25 \pm 0.25$ \\
\hline 0.25 & 2123 & 189 & $8.90 \pm 0.26$ & 17.82 & 4 & 4 & 4 & 1 & - & 2 & 1 & 1 & $0.80 \pm 0.61$ \\
\hline 0.50 & 2041 & 172 & $8.42 \pm 0.26$ & 22.16 & 8 & 6 & 5 & 6 & 2 & 4 & 1 & 4 & $1.76 \pm 0.80$ \\
\hline 0.75 & 2214 & 167 & $7.80 \pm 0.27$ & 27.98 & 7 & 9 & 8 & 3 & 3 & 3 & 2 & 3 & $1.77 \pm 0.98$ \\
\hline 1.00 & 2201 & 161 & $7.31 \pm 0.26$ & 33.50 & 8 & 8 & 7 & 7 & 1 & 4 & 2 & 2 & $1.77 \pm 1.00$ \\
\hline
\end{tabular}

\section{Discussion}

Generally, the development of new chemotherapeutic agents from plants have made them important sources of potentially useful compounds ${ }^{44}$. The identified organisms (Escherichia coli, Klebsiella pneumoniae, Pseudomonas aeruginosa, Proteus mirabilis and Staphylococcus saprophyticus) from the semen of patients with secondary infertility following cultural, morphological and biochemical tests were found similar to the organisms earlier reported by Ekhaise and Richard $^{6}$. This probably suggest that the organisms are common pathogens associated with male infertility.

The aqueous extract of $C$. citratus leaves showed inhibitory activities against all the tested organisms, indicating a relatively good antimicrobial activity. This result is similar to earlier work by Ekhaise and Richard ${ }^{6}$, which isolated similar bacteria from the sperm of patients attending the infertility clinic of the University of Benin Teaching Hospital (UBTH), Nigeria, except for Psendomonas aeruginosa and, Proteus mirabilis which at the lowest concentration of the aqueous extract of $C$. citratus leaf showed no measurable zone of inhibition (Table 1). A previous report by Khan et $\mathrm{al}^{45}$ indicated that the aqueous extract of Calamus aromaticus leaf was ineffective against similar organisms (E. coli, P. mirabilis, S. saprophyticus) used in this study. This was however dissimilar to the observation obtained from this study. The antibacterial activity of the extract was observed to be concentration dependent. Furthermore, inhibition zones $\geq 10 \mathrm{~mm}$ are considered active ${ }^{46}$ which indicates that the aqueous extract was particularly active 
against S.saprophyticus and K.pueumoniae (Table1).The highest zone of inhibition was recorded against all the test organisms at the highest concentration of $50 \mathrm{mg} / \mathrm{ml}$. The antibiogram result of the reference drug was also most active at the highest concentration of $50 \mathrm{mg} / \mathrm{ml}$ (Table $3)$. It was observed that the extract of the plant was most effective against Staphylococcus saprophyticus (21.33 \pm 1.20 $\mathrm{mm})$ and moderate against Escherichiacoli (4.0 \pm 1.15

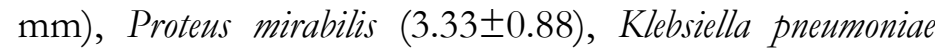
$(13.00 \pm 1.15 \mathrm{~mm})$ and Pseudomonas aeruginosa (NMZI).Two of the tested organisms have been previously implicated in food poisoning diseases- E. coli and P. aeruginosa47-49. This indicates the potential of the extract as an alternative source in combating the ailment though the activity was observed moderate against E. coli. The inhibitory effect of the diluent-10\% DMSO was insignificant. The test organisms can be considered susceptible to the extract and positive control when the MIC values were compared with MIC break point values $(8 \mathrm{mg} / \mathrm{ml})$ elsewhere ${ }^{50}$. It was observed from the minimum inhibitory concentration (MIC) values presented in Tables 2, that the highest MIC of $3.13 \mathrm{mg} / \mathrm{ml}$ was recorded against Proteus mirabilis while Staphylococcus saprophyticus, Klebsiella pneumonia and Escherichia coli had the same MIC value of $1.56 \mathrm{mg} / \mathrm{ml}$. The extract at $3.13 \mathrm{mg} / \mathrm{ml}$ had same bacteriocidal activity against all the test organisms (Table 2).

The qualitative phytochemical analysis carried out on both the aqueous extract and crude sample of C.citratus leaf revealed that the plant had a good number of secondary metabolites (Saponin, flavonoids, glycosides, carbohydrates, steroids, terpenoids, and alkaloids) (Table 4). These bioactive components are important and have shown to have medicinal and physiological effects ${ }^{39}$. Saponins have been reported to have antifungal properties ${ }^{51}$ while steroids was reported by $\mathrm{Okwu}^{52}$ to be important and of interest to pharmacy as it is the starting material in the synthesis of sex hormones. The presence of these phytochemicals in $C$. citratus leaves suggest the plant is pharmacologically active which lend supports to claims of its ethnomedical uses.

Interestingly, proximate analysis of plants (medicinal, edible fruits and vegetables) had been shown to play crucial role in assessing their nutritional significance and deepen the understanding of the values of these plants ${ }^{14}$. It was observed that nitrogen free energy (carbohydrate) had a reasonably high percentage composition of
$47.01 \pm 0.012 \%$ in the crude sample as against $29.61 \pm 0.005$ in the aqueous extract of $C$. citratus leaves (Table 5).

The aqueous extract of $C$. citratus displayed a relatively cytogenotoxic activity against the Allium cepa roots. The macroscopic parameters (morphology) observed during the root growth of the Allium cepa differs in respect to the different concentrations of the extract (Table 6). The average root length were found to be between 1.84-2.74 $\mathrm{cm}$ at a concentration range of $0.25-1 \mathrm{mg} / \mathrm{ml}$ as against a measured root length varying between $3.79-5.76 \mathrm{~cm}$ recorded for Artemisia annua at a concentration range of $450-1800 \mathrm{mg} / \mathrm{ml}^{53}$. The genotoxic and cytotoxic effect of the extract became apparent following the different number of chromosomal aberrations noted (Figure 1). The Sticky chromosomes observed probably occurred due to the degradation or depolymerization of chromosome $\mathrm{DNA}^{18}$ or as a result of DNA condensation and stickiness of inter- chromosome fibers ${ }^{54}$. The occurrence of these aberrationssuggest the plant may be genotoxic and in turn can be a good anti-tumour agent. A reduction in the number of dividing cells as the concentration of the extract increased was noticed. This has also been found in a similar report by Timothy et $\mathrm{al}^{1}$, while assessing the cytogenotoxic effect of Icacina tricantha leaf extract. This is an indication of the mitodepressive effect of the extract on the cell division of the onion which also reflect the potential ability of the extract to block DNA synthesis and nucleus-proteins. The mitotic index values were found to be lower when compared to the control (Table 7). Increased in the concentration of the aqueous extract of $C$. citratus showed a decreased in the mitotic index values and the number of aberrant cells was also observed to increase with the concentrations. This decreased mitotic index values suggest that the plant may be toxic at the tested concentrations.

\section{Conclusion}

According to these findings, the aqueous extract of $C$. citratus had inhibitory activities against the pathogenic organisms isolated from semen. The findings also reveal the plant contain bioactive chemical compounds. The observed antibacterial activities of the extract justify some of the folkloric claims of the plant in treating infectious diseases whereas the cytogenic effects calls for caution while consuming the plant. It is recommended that further clinical studies be carried out on the isolated pathogens and other associated infectious pathogen. 


\section{Conflict of interest statement}

The authors declare that no conflict of interest exist.

\section{Acknowledgements}

The authors wish to thank Prof. Dan Olorunfemi and Mr. Romeo Ofomata of the Cytogenetics and Environmental Mutagenesis Laboratory for their technical assistance in carrying out the cytogenotoxic studies. The authors are also grateful to Mr. Efenudu Isaiah of the General Laboratory Unit in the Faculty of Agricultural Sciences, University of Benin for his assistance technically in the phytochemical analysis. The support of the University of Pretoria is also acknowledged.

\section{References}

1. Timothy O, Idu M, Olorunfemi D, Ovuakporie-Uvo O. Cytotoxic and genotoxic properties of leaf extract of Icacina trichantha Oliv. S Afr J Bot. 2014; 91:71-74.

2. Idu M, Onyibe H, Timothy O, Erhabor JO. Ethnomedicinal flora of Otuo people of Edo State, Nigeria. Asian J Plant Sci. 2008; 7:8-12.

3. Hoareau L, DaSilva EJ. Medicinal plants: a re-emerging health aid. Electron J Biotechnol. 1999; 2(2):3-4.

4. Enwereji E. Views on tuberculosis among the Igbo of Nigeria. Indig Know Dev Monitor. 1999; 7:4-7.

5. Onemu S, Ogbimi A, Ophori E. Microbiology and semen indices of sexually-active males in Benin City, Edo State, Nigeria. Afr J Bacteriol Res.2010; 2(5):55-59.

6. Ekhaise F, Richard F. Common bacterial isolates associated with semen of men complaining of infertility in University of Benin Teaching Hospital (UBTH), Benin City, Nigeria. World J Med Sci. 2008; 3(1):28-33.

7. Pellati D, Mylonakis I, Bertoloni G, Fiore C, Andrisani A, Ambrosini G, Armanini D. Genital tract infections and infertility. Eur J Obstet Gynecol Reprod Biol. 2008; 140(1):311.

8. Sanocka-Maciejewska D, Ciupińska M, Kurpisz M. Bacterial infection and semen quality. J Reprod Immunol. 2005; 67(1-2):51-56.

9. Keck C, Gerber-Schäfer C, Clad A, Wilhelm C, Breckwoldt M. Seminal tract infections: impact on male fertility and treatment options. Human Reprod Update. 1998; 4(6):891-903.

10. Purvis K, Christiansen E. Infection in the male reproductive tract. Impact, diagnosis and treatment in relation to male infertility. Int J Androl. 1993; 16(1):1-13.
11. Haidl G. Macrophages in semen are indicative of chronic epididymal infection. Arch Androl. 1990; 25(1):511.

12. Ibadin O, Ibeh I. Bacteriospermia and sperm quality in infertile male patient at University of Benin Teaching Hospital, Benin City, Nigeria. Malays J Microbiol. 2008; 4(2):65-67.

13. Erhabor JO, Idu M, Udo F. Ethnomedicinal survey of medicinal plants used in the treatment of male infertilty among the IFA Nkari People of Ini Local Government area of Akwa Ibom State, Nigeria. Res J Rec Sci. 2013; 2:5 -11.

14. Pandey M, Abidi A, Singh S, Singh R. "Nutritional evaluation of leafy vegetable Paratha". J Hum Ecol. 2006; 19(2):155-156.

15. Shah G, Shri R, Panchal V, Sharma N, Singh B, Mann AS. Scientific basis for the therapeutic use of Cymbopogon citratus Stapf (Lemon grass). I Advan Pharma Technol Res. 2011; 2(1):3-8.

16. Olorunnisola SK, Hammed AM, Simsek S. Biological properties of Lemongrass: An overview. Int Food Res J. 2014; 21(2):455-462

17. Kasper D, Fauci A, Hauser S, Longo D, Jameson J, Loscalzo J. Harrison's Principles of Internal Medicine, 19e. 2015.

18. Grant WF. Chromosome aberration assays in Allium: A report of the US Environmental Protection Agency gene-tox program. Mut Res. 1982; 99(3):273-291.

19. Smaka-Kincl V, Stegnar P, Lovka M, Toman MJ. The evaluation of waste, surface and ground water quality using the Allium test procedure. Mut Res. 1996; 368(34):171-179.

20. Cabuga Jr CC, Abelada JJZ, Apostado RRQ, Hernando BJH, Lador JEC, Obenza OLP, Presilda CJR ,Havana HC.Allium cepa test: An evaluation of genotoxicity. Proc Int Acad Ecol Environ Sci. 2017;7(1):12-19.

21. Abusalma E, Elhassan A, Errami M, Salghi R. Pesticides Residues: Endosulfan and DDT in Cow's milk in Gezira State, Sudan. Mor J Chem. 2014; 2(3):125-135.

22. Bakadir K, Kassale A, Barouni K, Lakhmiri R, Albourine A. Retention of a compound of herbicides, 2, 4-dichlorophenoxy acetic acid, to a soil in the absence and in the presence of $\mathrm{Cu}$ (II) and $\mathrm{Zn}$ (II) cations. J Mat Environ Sci. 2016; 7(3):1056-1063.

23. Fiskesjö G. The Allium test-an alternative in environmental studies: the relative toxicity of metal ions. Mut Res. 1988; 197(2):243-260. 
24. Chungsamarnyart N, Jiwajinda S. Acaricidal activity of volatile oil from Lemon and Citronella grasses on tropical cattle ticks. Kasetsart J 1992; 26:46-51.

25. Lorenzetti BB, Souza GE, Sarti SJ, Santos Filho D, Ferreira SH. Myrcene mimics the peripheral analgesic activity of lemongrass tea. J Ethnopharmacol. 1991; 34(1):4348.

26. De Blasi V, Debrot S, Menoud P, Gendre L, Schowing J. Amoebicidal effect of essential oils in vitro. $J$ Toxicol Clin Exp. 1990; 10(6):361-373.

27. Onawunmi GO, Yisak W-A, Ogunlana E. Antibacterial constituents in the essential oil of Cymbopogon citratus (DC.) Stapf. J Ethnopharmacol. 1984; 12(3):279-286.

28. Syed M, Khalid MR, Chaudhary FM. Essential oils of Graminae family having antibacterial activity Part 1. (Cymbopogon citratus, C.martinii and C.jawarancusa oils. Pak J Sci Ind Res. 1990; 33:529- 531.

29. Carlini EA, Contar JDD, Silva-Filho AR, Da Silveira-Filho NG, Frochtengarten ML, Bueno OF. Pharmacology of Lemongrass (Cymbopogon citratus Stapf). I. Effects of teas prepared from the leaves on laboratory animals. $J$ Ethnopharmacol. 1986; 17(1):37-64.

30. Suresh M, Raj RK. Cardol: the antifilarial principle from Anacardium occidentale. Curr Sci. 1990:477-479.

31. Lemos T, Matos FDA, Alencar J, Craveiro A, Clark A, McChesney J. Antimicrobial activity of essential oils of Brazilian plants. Phytother Res.1990; 4(2):82-84.

32. Audicana M, Bernaola G. Occupational contact dermatitis from citrus fruits: lemon essential oils. Contact Derm.1994; 31(3):183-185.

33. Carbajal D, Casaco A, Arruzazabala L, Gonzalez R, Tolon Z. Pharmacological study of Cymbopogon citratus leaves. J Ethnopharmacol. 1989; 25(1):103-107.

34. Rao VS, Dasaradha P, Krishnaiah. Antimalarial effect of some indigenous plant. Indian J of Medical Res. 1982; 70:517-520.

35. Cáceres A, Girón LM, Alvarado SR, Torres MF. Screening of antimicrobial activity of plants popularly used in Guatemala for the treatment of dermatomucosal diseases. J Ethnopharmacol. 1987; 20(3):223-237.

36. Cheesbrough M.District laboratory practice in tropical countries: Cambridge university press; 2006.

37. Emeruwa A. Antibacterial substance from Carica papaya fruit extract. J Nat Prod. 1982; 45(2):123-127.
38. Eloff JN. A sensitive and quick microplate method to determine the minimal inhibitory concentration of plant extracts for bacteria. Planta Med. 1998; 64(08):711-713.

39. Sofowora A.Medicinal Plants and Traditional Medicine in Africa. . Ibadan, Nigeria: Spectrum Books Limited; 1993.

40. Trease G. Trease and Evans Pharmacognosy, 14th edition wb Ssuvnder company limited. London.1996; pp191-293.

41. Horwitz W, Latimer G. Official Methods of Analysis of AOAC International, Gaithersburg MA, USA. Association of Official Analytical chemist 2000.

42. Olorunfemi D, Ogieseri U, Akinboro A. Genotoxicity screening of industrial effluents using onion bulbs ( $A l$ lium cepa L.). J Appl Sci Environ Manage. 2011; 15(1):211216.

43. Sharma C. Plant meristems as monitors of genetic toxicity of environmental chemicals. Curr Sci. 1983:10001002.

44. Idu M, Asowata I, Erhabor, JO. . Preliminary antimicrobial and Phytochemical study of the aqueous, ethanol, methanol and chloroform extracts of the leaves of $\mathrm{Na}$ poleona imperialis P. Beauv. (Lecythidiaceae). J Plant Dev Sci. 2011; 3: 225 - 231.

45. Khan BM, Bakht J, Shafi M. Screening of leaves extracts from Calamus aromaticus for their antimicrobial activity by disc diffusion assay. Pak J Pharm Sci. 2017; 30(3):793-800.

46. Usman H, Haruna A, Akpulu I, Ilyas M, Ahmadu A, Musa Y. Phytochemical and antimicrobial screenings of the leaf extracts of Celtis integrifolia Lam. J Trop Biosci. 2005; 5(2):72-76.

47. Solomakos N, Govaris A, Koidis P, Botsoglou N. The antimicrobial effect of thyme essential oil, nisin and their combination against Escherichia coli. O157: H7 in minced beef during refrigerated storage. Meat Sci. 2008; 80(2):159-166.

48. Pandey A, Singh P. Antibacterial activity of Syzygium aromaticum (clove) with metal ion effect against food borne pathogens. Asian J Plant Sci Res. 2011; 1(2):69-80.

49. Mostafa AA, Al-Askar AA, Almaary KS, Dawoud TM, Sholkamy EN, Bakri MM. Antimicrobial activity of some plant extracts against bacterial strains causing food poisoning diseases. Saudi J Bioll Sci. 2018; 25(2):361-366. 
50. Andrews J. BSAC standardized disc susceptibility testing method (version 4). J Antimicrob Chemother. 2005; 56(1):60-76.

51. Sodipo O, Akanji M, Kolawole F, Odutuga A. Saponin is the active antifungal principle in Garcinia kola, Heckle seed. Biosci Res Commun. 1991; 3:171.

52. Okwu D. Evaluation of chemical composition of in- deginous species and flavouring agents. Global J Pure Appl Sci. 2001; 7(3):455-460.

53. Karaismailoglu MC. Investigation of the Cytotoxic and Genotoxic Effects of Artemisia annua methanol extract with the Allium Test. Ekoloji Derg. 2014; 23(91). 54. Schneiderman MH, Dewey W. C. and Highfieid D. P. . Inhibition of DNA synthesis in synchronized Chinise hamster cells treated in G1 with cyclohexamid. Exp Cell Res. 1971; 67:147 - 155 . 